\title{
An Analysis of Grammatical Metaphor Representation and Transgrammatical Semantic Domains in Narrative Text Entitled Three Fishes
}

Maria Olivia Christina Sianipar ${ }^{1}$

${ }^{1}$ English Applied Linguistics Study Program, Postgraduate Studies The State University of Medan, Indonesia

\begin{tabular}{l}
\hline \hline ARTICLE INFO \\
\hline \hline Article history: \\
Received February 25, 2019 \\
Revised April 02, 2019 \\
Accepted June 02, 2019 \\
\hline Keywords: \\
Grammatical metaphor, \\
Transgrammatical semantic \\
domain, \\
Narrative text \\
\hline Clonflict of Interest: \\
None
\end{tabular}

Funding:

None \begin{abstract}
This research is aimed to find out the easy way for students in Indonesia to understand and to translate English text to Bahasa Indonesia. In doing this research, the researcher uses a form of a detailed examination of one setting a single subject, a single depository of documents or one particular even which is stated by Bogdan \& Biklen (1992:62) as a case study. However, the descriptive qualitative research as stated by Miles, Huberman and Saldana (2014) is applied in analyzing the data. Researcher realizes that Indonesian students are still very difficult to understand and translate the English texts as the texts are coded in grammatical metaphor. Although Indonesian students already get English lesson from grade school or at junior high school, but still they are difficult to understand and translate any kinds of English text. It is expected by applying transgrammatical semantic domains Indonesian students can understand the texts and can translate the English text into good Bahasa Indonesia. This narrative text entitled 'Three Fishes' which is a short interesting story that has a good lesson, that makes easy to understand about the topic of this research that is knowledge or competence of Grammatical Metaphor and Transgrammatical Semantic in Text which is written in English. This way Indonesian students will be more interesting to read the text because they can understand and translate the text into Bahasa Indonesia easier.
\end{abstract}

Corresponding Author: Maria Olivia Christina Sianipar, English Applied Linguistics Study Program, Postgraduate Studies The State University of Medan, Indonesia. Email: mariasianipar919@yahoo.com

Copyright $(\odot)$ Association of Language Teachers in Southeast Asia. All rights reserved

\section{Introduction}

Indonesian students are still very difficult to understand and translate English texts as the texts are coded in grammatical metaphor. Although Indonesian students already get English lesson from grade school or at junior high school, but still they are difficult to understand and translate any kinds of English text. That is the reason the researcher makes 
this research to give some better ways for learning English as a foreign language that focused on ideational metaphor, which mainly involves texts of science, technology and academics. It is expected by applying transgrammatical semantic domains Indonesian students can understand the texts better. This research is focused on ideational metaphor, which mainly involves texts of science, technology and academics. In this case, researcher chooses narrative text of grammatical metaphor and transgrammatical semantic domain in doing this research. This way Indonesian students will be more interesting to read the text because they can understand and translate the text into Bahasa Indonesia easier. In this case, the reader can translate this narrative text entitled 'Three Fishes' into Bahasa Indonesia interestingly and easier.

There is some reason why this research to be done. First, the need of documentation for the practical and scientific needs in the future. The second is for the researcher herself as the strategy to teach English as a foreign language. The preliminary research of this study shows the students are lack of reading because they are difficult to understand and translate the text which are coded in grammatical metaphor and transgrammatical semantic domain. To get the real data of this research, the researcher formulates the research problem by the following question: Is the application of grammatical metaphor and transgrammatical semantic domain more effective than conventional teaching English as a foreign language for Indonesian students?

This research firstly addresses both grammatical metaphor representation and transgrammatical semantic domains. Secondly, both aspects of grammatical metaphor and transgrammatical semantic domain are applied to English language learning by which Indonesians learners can better understand the various kinds of texts. Finally, this research proposes steps in teaching the grammatical metaphor by applying transgrammatical semantic domain.

Grammatical metaphor representation indicates as if a text were expressed in another grammatical coding. This is to say that an experience or meaning, which is commonly coded in a normal or common wording, is now expressed in another mode of wording. This implies that grammatical metaphor involves two layers of coding, namely the congruent and incongruent or metaphorical one. The congruent or literal coding indicates that there is a natural relation between meaning (semantics) and wording (grammar) in the coding. The incongruent representation shows that the natural coding is violated. In other words, in grammatical metaphor there is a tension between meaning and wording or between semantics and grammar (Martin and Rose, 2007: 229). Grammatical metaphor divides into ideational and interpersonal metaphor (Halliday, 2014: 707; Thompson, 2014: 253). This paper is focused on ideational metaphor, which mainly involves texts of science, technology and academics.

Transgrammatical semantic domains extend meanings across different grammatical units (Halliday, 2014: 665). In other words, agnate meanings are potentially coded by more than one grammatical aspect. This implies that grammatical metaphor inherently involves transgrammatical semantic domain.

\section{Literature Review}

\subsection{There are some categories of Grammatical Metaphor.}

Systematic-functional linguists divided grammatical metaphor into three types: ideational metaphor, interpersonal metaphor and textual metaphor according to the classification of Metafunctions. Aiming at the phenomenon that metaphor appears mainly in the lexical level and there is a deviation to semantic rules, Halliday believed that in language

SALTeL Vol. 2, No. 2, July 2019: 15 - 29 
expression, the grammar form can be chosen freely to express a same meaning. He called this "grammatical metaphor" and made detailed analysis with the help of Metafunctional theories in systematic-functional grammar.

\subsection{Ideational Metaphor.}

Halliday divided grammatical metaphor into two groups: ideational metaphor and interpersonal metaphor. One semantic process is presented by another process; other functional elements like participants and circumstances change correspondingly. This is called ideational metaphor. Ideational metaphor can be further divided into three levels: (1) the transition of process, which means in the transitivity system, each process can be Metaphorized mutually; (2) the transition of functional components, which means the mutual metaphorization of different elements in the process; (3) the transition of vocabulary and grammar, which means that the transferred functional components are metaphorized from established forms to other forms in the lexical and grammatical levels.

\subsection{Interpersonal Metaphor.}

Interpersonal metaphor can be divided into metaphor of modality and metaphor of mood. The former means that in the system of interpersonal function, clauses without modal elements are chosen to express certain modality instead of modal verbs and modal adverbs in the process of forming interpersonal metaphor. The latter means that the speaker employs a kind of mood, which has crossing relation with the given verbal function. The consistent principle is violated, which means that declarative function is not always expressed by indicative mood; interrogative function is not always expressed by interrogative mood; injunctive function is not always expressed by imperative mood.

\subsection{Textual Metaphor.}

Halliday had discussed ideational metaphor and interpersonal metaphor in detail in his book An Introduction to Functional Grammar, but he never mentioned textual metaphor in it. The doubt of whether textual metaphor exists is raised. According to lots of researches by many linguists, there is textual metaphor in language indeed.

\subsection{Grammatical Metaphor.}

Halliday's approach relies on the fact that there are different choices of grammatical structures, congruent and incongruent ones. Grammatical metaphor is conceived as an incongruent realization of a given semantic configuration in the lexicogrammar (1985: $321)$.

The concept of grammatical metaphor depends on the idea that there is a direct line of form to meaning to experience (1985: xix). As far as Halliday is concerned the lexicogrammar is a natural symbolic system. This means "...that both the general kinds of grammatical pattern that have evolved in language, and the specific manifestations of each kind, bear a natural relation to the meanings they have evolved to express" (Halliday 1985: xviii). There is a link between the categories of the grammar and reality. That is, grammar and reality are related in a congruent manner. This means that the direct line of form to meaning to experience is maintained intact.

But there also exists grammatical metaphor "whereby meanings may be cross-coded, phenomena represented by categories other than those that evolved to represent them" (Halliday

1985: xviii). In other words, for any semantic configuration there is one congruent expression and a set of metaphoric variants or incongruent expressions. This variation or incongruent expression is understood as a "selection of words that is different from that which is in some sense typical or unmarked" (Halliday 1985: 20). The different 
grammatical functions assigned to the participants in the clause structure express the different roles of these parts in respect to the whole and, for the selection in meaning; there will be a natural sequence of steps leading towards its realization. The underlying idea in this approach is that there is a hierarchy of semantic roles attached to the participants in the clause structure.

According to this hierarchy, we choose to function as the subject, first the agent, then, if we do not know the agent or do not want to mention it, we choose the affected, then, the effected, then, the goal, and so on. This is so because there is a natural relation between the participants and the semantic roles attached to them. "The selection of metaphor is itself a meaningful choice, and the particular metaphor selected adds further semantic features." (Halliday 1985: 321).

Grammatical metaphor refers to the coding of meaning or experience in the manner as if the meaning or experience were coded by another lexicogrammatical coding. Metaphorical representation implies that there are two manners of coding, namely the congruent or literal and incongruent or metaphorical coding. Transgrammatical semantic domains extend meaning by a range of grammatical units. Transgrammatical semantic coding implies that agnated meanings are realized by more than one semantic unit. Grammatical metaphor representation inherently contains transgrammatical coding.

Grammatical metaphor representation indicates as if a text were expressed in another grammatical coding. This is to say that an experience or meaning, which is commonly coded in a normal or common wording, is now expressed in another mode of wording. This implies that grammatical metaphor involves two layers of coding, namely the congruent and incongruent or metaphorical one. The congruent or literal coding indicates that there is a natural relation between meaning (semantics) and wording (grammar) in the coding. The incongruent representation shows that the natural coding is violated. In other words, in grammatical metaphor there is a tension between meaning and wording or between semantics and grammar (Martin and Rose, 2007: 229). Grammatical metaphor divides into ideational and interpersonal metaphor (Halliday, 2014: 707; Thompson, 2014: 253).

The term metaphor was coined by Aristotle, deriving from Greek Meta 'beyond' and pherein 'to carry' (Ross 1952). Thus, metaphor conveys meaning beyond that carried by words. Metaphor explains how people conceptualize abstractions in concrete ways (Danesi 2013: 189). In other words, metaphor converts understanding from concrete or sensory to abstract or cognitive perception. Danesi (2013: 189) exemplifies that the meanings of the words cat, table and tree are visible and concrete whereas that of life is abstract and cannot be perceived. However, by comparing life to something concrete such as stage in the text life is a stage, one gains a clear and concrete understanding of what this concept entails (at least in an imaginary way). With its characters, settings, and plots, the stage is felt to be an appropriate analogue for life. The theatre remains, to this day, an overarching metaphor for life. The theatre is even commonly used as a term to talk about life. For instance, if someone is asked what is your life like? one might get a response such as my life is a comedy or my life is a farce, from which one can draw real inferences about that person's life.

Halliday (2014: 29) observes that experience is potentially metaphorized. Prior to this, Halliday and Matthiessen (2006: 227) have elaborated that there are two ways of coding meaning or experience, namely coding experience literally or congruently and incongruently or metaphorically. Both congruent and metaphorical coding potentially occur at the lexical and grammatical level, which correspondingly results in lexical and 
grammatical metaphor (Halliday and Matthiessen, 2006: 221-222). The congruent coding is relocated or transformed to incongruent or metaphorical one by associative thinking (Danesi, 2013: 191). In other words, a metaphorical coding inherently contains a comparison where similarities are found between two things or objects.

Lexical metaphor involves (an implicit) comparison between lexical items or words. For example, on one hand the text the snake is crawling on the grass is in congruent or literal coding with the word snake is normally or commonly meant 'an animal' or 'a reptile'. On the other hand, at the lexical level the text does not trust Dianne; she is a snake is a metaphorical coding where Dianne is compared to snake. In other words, there is a comparison between snake and Dianne. With reference to lexical semantics, the features of the word snake are generatively described as [+scale, +coil, +crawl, +poisonous], where the sign + means 'apply'. The four features of snake are mapped on to and compared with those of Dianne as a human being with the semantic features as [-scale, +coil, -crawl, +poisonous], where - means 'not apply'. The comparison indicates that Dianne possesses two out of four features of snake. In other words, Dianne shares proportionally about $50 \%$ of the semantic features of. As there are similarities between a snake and Dianne or there coexist features of snake and Dianne, there is a strong basis or ground to metaphorize Dianne as a snake as realized in the text Dianne is a snake. In lexical metaphor a comparison occurs between two words. The following examples of lexical metaphor indicates comparisons between (1) noun-noun: the door of his heart, the root of the matter, the island of hope, the eye of her heart, the foot of the hill... (2) Verb-noun: curb his passion, open his heart, warm up the political situation, an idea sparks, break the rules... (3) Adjective-noun: dark age, bright future, golden age, happy hours, cloudy life...

Grammatical metaphor can be well understood by referring to lexical metaphor. Analogous to congruent or literal meaning of lexical metaphor, the congruent coding of grammatical metaphor is seen in the relation between meaning and wording or between semantics and grammar. Grammatical metaphor covers ideational and interpersonal metaphor; however, in this paper only ideational metaphor is elaborated.

Ideational metaphor covers experiential and logical functions. Martin and Rose (2007: 74) observe that there is a common, normal or typical way of coding meaning in wording. In other words, there is a typical realization of meaning in wording. This typical coding is also known as congruent coding. If the typical coding is violated then grammatical metaphor is involved. In other words, if there is a tension between meaning or semantics or between wording and grammar, grammatical metaphor is resulted.

\subsection{Transgrammatical Semantic Domain}

Transgrammatical Semantic Domain extends a meaning across different grammatical units (Halliday, 2014: 665-666). This is to say that a meaning is potentially realized or coded by a range of grammatical units. The meanings coded by the various grammatical units are not synonymous as each coding has its own specific context or values. Transgrammatical semantic domains are semantically agnated or share a certain feature but they differ in other respects. Following Halliday (2014: 666) the meaning of 'addition' may be realized by a range of grammatical unit, where (1) cohesively join the two clauses by also or (2) structurally by (a) an additive paratactic clause nexus marked by the structural conjunction and, (b) a circumstance of accompaniment marked by the preposition with or (c) an additive paratactic group nexus marked by and: (1) She went to the market. Her son also went to the market. (2a) She went to the market and so did her son. (2b) She went to the market with her son. (2c) She and her son went to the market. All realizationally variants of meaning are dispersed in the grammar, since they constitute different grammatical 
environments; but they are semantically agnated in that they all have the feature of 'addition'. Another example is 'medium-value probability modality' is realized by (3a) modal verb will, (3b) modal adjunct probably, (3c) nominal group probability, (3d) epithet probable with it is...construction or (3e) grammatical metaphor of modality, I think. (3a) She will visit her brother who lives in Kisaran (3b) Probably she visits her brother who lives in Kisaran. (3c) There is a probability she visits her brother who lives in Kisaran (3d) It is probable that she visits her brother who lives in Kisaran. (3e) I think she visits her brother who lives in Kisaran.

\subsection{Narrative Text.}

According to Rebecca (2003), a narrative text is a text, which relates a series of logically, and chronologically related events that are caused or experienced by factors. She, furthermore, states that a key to comprehending a narrative is a sense of plot, of theme, of characters, and of events, and of how they relate. In addition, Anderson and Anderson (2003a) explain that a narrative is a text that tells a story and, in doing so, entertains the audience. It has character, setting, and action. The characters, the setting, and the problem of the narrative are usually introduced in the beginning. The problem reaches its high point in the middle. The ending resolves the problem.

The verb to narrate means to tell, to give all account of Writing narrative is really just putting what happen to somebody on paper (Widayati, 2003). In narrative, the incidents that make up the story are usually told in the order in which they would really happen. A narrative can tell what happens in a matter of minutes or years. A narrative text usually contains with features of characters, main character(s), setting, time, problem(s), solution, and a plot (structure). Some authors use plot, structure, or rhetorical step interchangeably.

According to Diana (2003), a narrative text usually has description of features and rhetorical steps. The generic structures of a narrative comprise three points: orientation, complication, and resolution. The other two components as proposed by Anderson and Anderson (2003b) are just variations or can even be considered as optional since the two are not differently essentially.

Narrative text may take many kinds or forms. They are myths, fairytales, aboriginals, science, fiction, dreaming stories/bedtime stories, and romance novels. Among those forms, fairy tales or fairy story has lots of sub-forms: fairies, goblins, elves, trolls, giants, and talking animals.

The purpose of a narrative, other than providing entertainment, can be to make the audience think about an issue, teach them a lesson, or excite their emotions. In well-written narration, a writer uses insight, creativity, drama, suspense, humor, or fantasy to create a central theme or impression. The details all work together to develop an identifiable story line that is easy to follow and paraphrase.

\section{Research Method}

This research is a research of a detailed examination of one setting a single subject, a single depository of documents or one particular even which is stated by Bogdan \& Biklen (1992: 62) as a case study. This is also a descriptive qualitative research as stated by Miles, Huberman \& Saldana (2014) is applied in analyzing the data.

\section{Data and Analysis}

\section{"Three Fishes".}

Once, three fishes lived in a pond. One evening, some fishermen passed by the pond and saw the fishes. 'This pond is full of fish', they told each other excitedly. 'We have never 
fished here before. We must come back tomorrow morning with our nets and catch these fish!' Then the fishermen left.

When the eldest of the three fishes heard this, he was troubled. He called the other fishes together and said, 'Did you hear what the fishermen said? We must leave this pond at once. The fishermen will return tomorrow and kill us all!' The second of the three fishes agreed. 'You are right', he said. 'We must leave the pond.'

But the youngest fish laughed. 'You are worrying without reason', he said. 'We have lived in this pond all our lives, and no fisherman has ever come here. Why should these men return? I am not going anywhere - my luck will keep me safe.'

The eldest of the fishes left the pond at very evening with his entire family. The second fish saw the fishermen coming in the distance early next morning and left the pond at once with all his family. The third fish refused to leave even then.

The fishermen arrived and caught all the fish left in the pond. The third fish's luck did not help him - he was also caught and killed.

The fish that saw trouble ahead and acted before it arrived as well as the fish that acted as soon as it came both survived. But the fish that relied only on luck and did nothing at all died.

Table 1: Congruent Representation of Semantics in Grammar

\begin{tabular}{cccl}
\hline No. & Meaning (Semantics) & Function and Grammar & \multicolumn{1}{c}{ Examples } \\
\hline 1. & Thing & Participant/noun & $\begin{array}{l}\text { Three fishes lived in a } \\
\text { pond. }\end{array}$ \\
& & $\begin{array}{l}\text { Some fishermen passed } \\
\text { by the pond. }\end{array}$ \\
& & & $\begin{array}{l}\text { Three fishes lived in a } \\
\text { pond. }\end{array}$
\end{tabular}

Some fishermen passed by the pond and saw the fishes. They told each other excitedly. 'We have never fished here before. We must come back tomorrow morning with our nets and catch these fish!' Then the fishermen left. The eldest of the three fishes heard this. $\mathrm{He}$ called the other fishes together and said 'We must leave this pond at once'. The fishermen will return tomorrow and kill us all'. The second of the three fishes agreed,' We must leave the pond'. The youngest fish laughed, 'You are worrying without reason'. 'I am not 
going anywhere. My luck will keep me safe.' The eldest of the fishes left the pond at very evening with his entire family. The second fish saw the fishermen coming in the distance early next morning and left the pond at once with all his family. The third fish refused to leave even then.

The fishermen arrived and caught all the fish left in the pond. The third fish's luck did not help him - he was also caught and killed.

The fish who saw trouble ahead and acted before it arrived as well as the fish who acted as soon as it came both survived. But the fish that relied only on luck and did nothing at all died.

\begin{tabular}{|c|c|c|c|}
\hline 3. & Quality & Attribute/adjective & $\begin{array}{l}\text { This pond is full of fish. } \\
\text { He was troubled. }\end{array}$ \\
\hline 4. & Relation & $\begin{array}{c}\text { Parataxis - hypotaxis/ } \\
\text { Conjunction }\end{array}$ & $\begin{array}{l}\text { Then the fishermen left. } \\
\text { But the youngest fish } \\
\text { laughed. }\end{array}$ \\
\hline 5 . & Location, Manner & Circumstance/adverb & $\begin{array}{l}\text { They talked each other } \\
\text { excitedly. } \\
\text { The second fish saw the } \\
\text { fishermen coming in the } \\
\text { distance early next } \\
\text { morning and left the pond } \\
\text { at once. }\end{array}$ \\
\hline 6. & Comment, Judgment & Modality & $\begin{array}{l}\text { The fishermen will return } \\
\text { tomorrow. We must come } \\
\text { back tomorrow morning. } \\
\text { We must leave this pond. }\end{array}$ \\
\hline 7. & Position & Preposition & $\begin{array}{l}\text { Three fishes lived in a } \\
\text { pond. }\end{array}$ \\
\hline
\end{tabular}


Table 2: Metaphorical Representation

\begin{tabular}{|c|c|c|c|}
\hline No. & Class Metaphor & Function Metaphor & Examples \\
\hline \multirow[t]{8}{*}{1} & Adjective $\rightarrow$ Noun & Quality $\rightarrow$ Thing & Full $\rightarrow$ Fullness \\
\hline & & & Troubled $\rightarrow$ Trouble \\
\hline & & & Safe $\rightarrow$ Safeness \\
\hline & & & Lucky $\rightarrow$ Luck \\
\hline & & & Together $\rightarrow$ Togetherness \\
\hline & & & Dead $\rightarrow$ Death \\
\hline & & & Live $\rightarrow$ Living \\
\hline & Verb $\rightarrow$ Noun & Process $\rightarrow$ Thing & Return $\rightarrow$ Return \\
\hline \multirow[t]{4}{*}{2} & & & Fished $\rightarrow$ Fishing \\
\hline & & & Pass $\rightarrow$ Passing \\
\hline & & & Come $\rightarrow$ Coming \\
\hline & & & Come back $\rightarrow$ Return \\
\hline \multirow[t]{2}{*}{3} & $\begin{array}{l}\text { Tense/Phase Verb } \\
\text { (adverb) } \rightarrow \text { noun }\end{array}$ & Aspect of Process $\rightarrow$ Thing & $\begin{array}{l}\text { All our lives } \rightarrow \text { Entire our } \\
\text { lives }\end{array}$ \\
\hline & & & $\begin{array}{l}\text { His entire family } \rightarrow \text { The } \\
\text { whole family of him. }\end{array}$ \\
\hline \multirow[t]{2}{*}{4} & $\begin{array}{l}\text { Modality Verb } \\
\text { (adverb) } \rightarrow \text { Noun }\end{array}$ & Modality of Process $\rightarrow$ Thing & $\begin{array}{l}\text { Can / could } \rightarrow \text { Possibility, } \\
\text { Potential }\end{array}$ \\
\hline & & & $\begin{array}{l}\text { Will/would } \rightarrow \text { Possibility, } \\
\text { Potential }\end{array}$ \\
\hline 5 & $\begin{array}{l}\text { Verb }+ \text { Adverb/Prep. } \\
\text { phrase } \rightarrow \text { noun }\end{array}$ & $\begin{array}{c}\text { Process }+ \text { Circumstance } \rightarrow \\
\text { Thing }\end{array}$ & $\begin{array}{l}\text { They talked each other } \rightarrow \\
\text { Chat }\end{array}$ \\
\hline 6 & $\begin{array}{l}\text { Noun Head } \rightarrow \text { Noun } \\
\text { Premodifier }\end{array}$ & Thing $\rightarrow$ class of thing & $\begin{array}{l}\text { The youngest fish laughed } \\
\rightarrow \text { The youngest fish laughing. }\end{array}$ \\
\hline 7 & $\begin{array}{l}\text { Noun Head } \rightarrow \text { Prep. } \\
\text { Phrase Post Modifier }\end{array}$ & Thing $\rightarrow$ Possessor & $\begin{array}{l}\text { The fishermen arrived } \rightarrow \\
\text { The arrival of the fishermen }\end{array}$ \\
\hline 8 & $\begin{array}{l}\text { Noun Head } \rightarrow \\
\quad \text { Possessive }\end{array}$ & Thing $\rightarrow$ Possessor (of thing). & $\begin{array}{l}\text { The youngest fish } \\
\text { (laughed) } \rightarrow \text { The youngest } \\
\text { fish (laughter). }\end{array}$ \\
\hline 9 & Verb $\rightarrow$ Adjective & Process $\rightarrow$ Quality & $\begin{array}{l}\text { My luck is keeping me safe } \\
\rightarrow \text { Safe my luck }\end{array}$ \\
\hline 10 & $\begin{array}{l}\text { Tense / Phase Verb } \\
\text { (Adverb) } \rightarrow \text { Adjective }\end{array}$ & Aspect of process $\rightarrow$ Quality & Are right $\rightarrow$ Being right \\
\hline 11 & $\begin{array}{l}\text { Modality Verb } \\
\text { (Adverb) } \rightarrow \text { Adjective }\end{array}$ & Modality of process $\rightarrow$ Quality & $\begin{array}{l}\text { Will } \rightarrow \text { Probable } \\
\text { Should } \rightarrow \text { Probable }\end{array}$ \\
\hline \multicolumn{4}{|l|}{12} \\
\hline & Adverb $\rightarrow$ Adjective & $\begin{array}{l}\text { Manner Circumstance } \rightarrow \\
\text { Quality }\end{array}$ & $\begin{array}{l}\text { They talked each other } \\
\text { excitedly } \rightarrow \text { Excited Talk. }\end{array}$ \\
\hline
\end{tabular}



13 Conjunction $\rightarrow$
Relator $\rightarrow$ Quality
but $\rightarrow$ in contrary
Adjective
14 Conjunction $\rightarrow$ Verb
Relator $\rightarrow$ Process
and $\rightarrow$ additional
and $\rightarrow$ complement
then $\rightarrow$ follow
so $\rightarrow$ lead to
15 Conjunction $\rightarrow$
Relator $\rightarrow$ Circumstance
so $\rightarrow$ as a result
Prepositional phrase

Table 3: Relocation of Grammatical Class

\begin{tabular}{cccc}
\hline No. & $\begin{array}{c}\text { Congruent } \\
\text { Representation }\end{array}$ & Metaphorical Representation & Relocation \\
\hline 1 & Acted & Action & Process/verb $\rightarrow$ Thing/noun \\
2 & Passed & Passing & Process/verb $\rightarrow$ Thing $/$ noun \\
3 & Fished & Fishing & Process/verb $\rightarrow$ Thing $/$ noun \\
4 & Agree & Agreement & Process/verb $\rightarrow$ Thing $/$ noun \\
5 & Laughed & Laughter & Process/verb $\rightarrow$ Thing $/$ noun \\
6 & Excitedly & Excitement & Process/verb $\rightarrow$ Thing $/$ noun \\
7 & Arrived & Arrival & Process/verb $\rightarrow$ Thing $/$ noun \\
\hline
\end{tabular}

Table 4: Metaphorical and Congruent Based Translation

\begin{tabular}{|c|c|c|c|c|}
\hline No & Metaphorical Text & Text & $\begin{array}{l}\text { Translation Based } \\
\text { on Metaphorical } \\
\text { text }\end{array}$ & $\begin{array}{l}\text { Translation } \\
\text { Based on } \\
\text { Congruent texts }\end{array}$ \\
\hline 1. & $\begin{array}{l}\text { Once upon a time, } \\
\text { there were three } \\
\text { fishes live happily in } \\
\text { a pond until the } \\
\text { fishermen saw them. } \\
\text { The fishermen were } \\
\text { very enthusiastic to } \\
\text { take the fishes in the } \\
\text { pond. They never } \\
\text { imagined found a } \\
\text { pond, which was } \\
\text { full of fishes. They } \\
\text { had a great plan to } \\
\text { come another day }\end{array}$ & $\begin{array}{l}\text { Once, three fishes } \\
\text { lived in a pond. } \\
\text { One evening, } \\
\text { some fishermen } \\
\text { passed by the } \\
\text { pond and saw the } \\
\text { fishes. 'This pond } \\
\text { is full of fish', } \\
\text { they told each } \\
\text { other excitedly. } \\
\text { 'We have never } \\
\text { fished here } \\
\text { before. We must } \\
\text { come back }\end{array}$ & $\begin{array}{l}\text { Sekali waktu, ada } \\
\text { tiga ikan hidup } \\
\text { bahagia di kolam } \\
\text { sampai para nelayan } \\
\text { melihat mereka. Para } \\
\text { nelayan sangat } \\
\text { antusias untuk } \\
\text { mengambil ikan di } \\
\text { kolam. Mereka tidak } \\
\text { pernah } \\
\text { membayangkan } \\
\text { menemukan kolam } \\
\text { yang penuh dengan } \\
\text { ikan. Mereka punya }\end{array}$ & $\begin{array}{l}\text { Suatu hari, tiga } \\
\text { ikan hidup di } \\
\text { sebuah kolam. } \\
\text { Suatu malam, } \\
\text { beberapa nelayan } \\
\text { melewati kolam } \\
\text { dan melihat ikan. } \\
\text { 'Kolam ini penuh } \\
\text { ikan', kata mereka } \\
\text { satu sama lain } \\
\text { dengan penuh } \\
\text { semangat. 'Kita } \\
\text { belum pernah } \\
\text { memancing di sini }\end{array}$ \\
\hline
\end{tabular}


for fishing. tomorrow

morning with our nets and catch these fish!' Then the fishermen left. rencana besar untuk sebelumnya. Kita

datang hari lain untuk memancing.

harus kembali besok pagi dengan

jala kita dan menangkap ikan ini! "Lalu para nelayan pergi.

Ketika ikan tertua dari tiga ikan mendengar ini, dia merasa terganggu. Dia memanggil ikan-ikan lain bersama-sama dan berkata, 'Apakah kalian mendengar apa yang dikatakan oleh para nelayan? Kita harus meninggalkan kolam ini sekaligus. Nelayan akan kembali besok dan membunuh kita semua! 'Ikan yang kedua dari tiga ikan setuju. "Kamu benar," katanya. "Kita harus meninggalkan kolam."

Tetapi ikan yang paling muda tertawa. 'Kamu khawatir tanpa alasan', katanya. 'Kita telah tinggal di kolam ini sepanjang hidup kita, dan tidak ada nelayan yang pernah datang ke

bungsu terus tertawa
dengan gagasan ikan
tertua. Ikan bungsu
tidak dapat
menerima alasan
meninggalkan kolam
karena mereka hidup
bahagia sepanjang
hidup mereka di
kolam itu. Ikan

three fishes was very sad since he heard the plan fishermen. He informed his fellow and suggested to their safety. The second fish was happy with the idea run away from the pond for their

3. To the contrary the youngest fish kept laughing with the fish. The youngest fish could not accept the reason of leaving the pond because they already have been living happily for entire their life
But the youngest fish laughed. 'You are worrying ever come here. Why should these men return? I am 


there. The third fish
would remain in the
same pond.
"Nothing to be
afraid of. My
fortune always safes
me from danger.
The fishermen
would not come
again", he said to the
eldest fish. The third
fish doesn't go any
where but still stay
in the same place.

not going
anywhere - my
luck will keep me
safe.'

ketiga akan tetap

berada di kolam

yang sama. "Tidak ada yang perlu ditakutkan.

Keberuntunganku akan selalu menyelamatkanku. Nelayan tidak akan pernah datang ke kolam ini lagi" katanya pada ikan tertua. Ikan yang bungsu tidak pergi kemanapun dan tinggal di kolam yang sama.

4. The time came for the eldest leaving for another place with his whole family. The second fish also left the pond when he saw the fishermen coming close to the pond. The strange thing was that the youngest fish was too stubborn, he even remains in the same pond with happily.
The eldest of the fishes left the pond at very evening with his entire family. The second fish saw the fishermen coming in the distance early next morning and left the pond at once with all his family. The third fish refused to leave even then.
Tiba saatnya bagi si sulung pergi ke tempat lain bersama seluruh keluarganya. Ikan kedua juga meninggalkan kolam ketika dia melihat para nelayan mendekati kolam. Yang aneh adalah begitu keras kepala; tetap di kolam dengan bahagia. bahwa ikan bungsu sini. Mengapa

orang-orang ini harus kembali?

Saya tidak pergi

ke mana pun keberuntungan saya akan membuat saya tetap aman. "
Ikan tertua meninggalkan kolam pada malam hari bersama seluruh keluarganya. Ikan kedua melihat para nelayan datang di kejauhan pagi berikutnya dan segera meninggalkan kolam bersama seluruh keluarganya. Ikan ketiga menolak untuk pergi walaupun nelayan sudah datang.

Para nelayan datang dan menangkap semua ikan yang tersisa di kolam.

Keberuntungan ikan ketiga tidak membantunya dia juga ditangkap dan dibunuh. 

third fish have to
accept the fate that
he has to be killed
and died; his fortune
could not save him
from the fishermen.

6. The eldest fish that had known about danger in the future so he was in a hurry saving itself and the second fish that heard there was danger that threatened he also acted to save itself. Not like the youngest fish that doesn't care about what was happening, but dreaming on its luck without doing anything. The same thing also happens in life.

\author{
keras kepala si \\ bungsu tidak bisa \\ menyelamatkannya \\ dari nelayan, ikan \\ bungsu akhirnya \\ dibunuh juga.
}

The fish who saw trouble ahead and acted before it arrived as well as the fish who acted as soon as it came both survived. But the fish that relied only on luck and did nothing at all died. So also, in life.

$\begin{array}{ll}\begin{array}{ll}\text { Ikan tertua yang tahu } \\ \text { tentang bahaya yang }\end{array} & \begin{array}{l}\text { Ikan yang melihat } \\ \text { masalah di depan } \\ \text { mengancam di masa } \\ \text { depan bertindak }\end{array} \\ \begin{array}{ll}\text { bersiap untuk } \\ \text { menyelamatkan }\end{array} & \begin{array}{l}\text { sebelum tiba } \\ \text { masalah, serta }\end{array} \\ \text { dirinya sendiri dan } & \text { bertindak segera } \\ \text { ikan kedua yang } & \text { setelah tahu ada } \\ \text { mendengar kabar } & \text { bahaya sehingga } \\ \text { yang berbahaya juga } & \text { keduanya selamat. } \\ \text { bertindak untuk } & \text { Tetapi ikan yang } \\ \text { menyelamatkan } & \text { hanya } \\ \text { dirinya sendiri. } & \text { mengandalkan } \\ \text { Tidak seperti ikan } & \text { keberuntungan } \\ \text { termuda yang tidak } & \text { dan tidak } \\ \text { peduli dengan apa } & \text { melakukan apa- } \\ \text { yang terjadi, tetapi } & \text { apa menjadi mati. } \\ \text { memimpikan } & \text { Begitu juga dalam } \\ \text { keberuntungannya } & \text { hidup. } \\ \text { tanpa melakukan apa } & \\ \text { pun. Hal yang sama } & \\ \text { juga terjadi dalam } & \\ \text { kehidupan. } & \\ & \end{array}$

Ikan tertua yang tahu tentang bahaya yang mengancam di masa depan sehingga dia bersiap untuk menyelamatkan dirinya sendiri dan ikan kedua yang mendengar kabar yang berbahaya juga bertindak untuk Tidak seperti ikan termuda yang tidak peduli dengan apa yang terjadi, tetapi memimpikan keberuntungannya pun. Hal yang sama kehidupan. kan yang melihat dan bertindak elum tiba masalah, serta kan yang bertindak segera setelah tahu ada bahaya sehingga keduanya selamat. Tetapi ikan yang keberuntungan dan tidak melakukan apaapa menjadi mati. Begitu juga dalam hidup.

\title{
Conclusion
}

From the above analysis, we can find that the theory of Metafunction is very useful to explain grammatical metaphor. Metaphor is not only an escape expression of vocabulary, but also an escape means of expression for grammatical forms. Grammatical metaphor provides a new angle of view vocabularies possess metaphorical function; grammatical forms possess metaphorical characteristic. On how to raise theoretical level for practical application, English learners and translators should adopt a more positive attitude.

Grammatical metaphor representation indicates that an experience or meaning is coded as if it were coded in another grammatical unit. The text of grammatical metaphor implies two ways of coding: congruent and incongruent or metaphorical one. In congruent coding there is a natural relation between the meaning and the wording or between semantics and grammar whereas in metaphorical coding there is a tension between semantics and grammar. In other words, if the congruent coding is violated, metaphorical representations occur. Texts of science, technology and academics are usually coded in grammatical metaphor. Transgrammatical semantic domain extends a meaning across different grammatical units. This is to say that a meaning is potentially realized by a number of 
grammatical units. By its natures grammatical metaphor involves transgrammatical semantic domains. This paper has elaborated that the meaning of metaphorical text is well understood by referring to its congruent coding.

People will be easy understanding the meaning of every kind of text and it makes people more interesting to read the text by knowing metafunction.

This paper has elaborated that the meaning of metaphorical text is well understood by referring to its congruent coding. In addition, referring to and considering the congruent coding of the text in the translation process potentially make translation of English metaphorical text into good and natural BI. In conclusion, the students' knowledge and competence in grammatical metaphor and transgrammatical semantic domains are useful and helpful to overcome the problems.

This Narrative Text entitled 'Three Fishes' is saying that you have to face the reality that happens to you which is bad or good, and whether you are ready or not. You have to be ready for making good actions for save yourself or your life every time. Dreaming good things is all right in certain case but not in all cases. Do not dreams too high or too much that you will be better without doing anything. Do not look down on events that happen in life. Everything can change and everything can happen. You can be good and even better when you do some actions for your life. Don't be lazy and do not expect everything is all right without effort and actions. Be wise and aware for everything so you can hinder the danger, which is coming to you.

\section{References}

Briones, Fortuny, Sastre and Pocovi. (2003). Grammatical Metaphors in Scientific English The Specialist, Vol. 24, No.2.

Dong, J. (2013). Interpersonal Metaphor in Legal Discourse: Modality in Crossexaminations. Journal of Language Teaching and Research, Vol. 4 No.6

Eggins, S. (2004). An Introduction to Systemic Functional Linguistics. New York: Continuum.

Griffiths, P. (2006). An Introduction to English Semantics and Pragmatics. Edinburgh: Edinburgh University Press.

Lakoff, G and Johnsen M. (2003). Metaphors we live by. London: The University of Chicago Press

Hadidi, Yaser. (2012). A comparative study of Ideational Grammatical Metaphor in Business and Political Texts. International Journal of Linguistics. Vol. 4 No.2

Halliday, M.A.K. (1985) b. Spoken and Written Language. Geelong, Vic.: Deakin University Press (republished by OUP, 1989).

Halliday, M. A. K. (2014). An Introduction to Functional Grammar. Fourth edition. London: Routledge.

Halliday, M. A. K. and C. M. I. M. Matthiessen. (2006). Construing Experience through Meaning: a Language Based Approach to Cognition. London: Continuum

Martin, J. R and D. Rose. (2007). Working with Discourse: Meaning Beyond the Clause.

Miles, Matthew B., A. Michael Huberman, Johnny Saldana. (2014). Qualitative Data. Analysis: A Methods Sourcebook. Thousand Oaks, CA: Sage

Robinson, S. K. (2011). Out of our Minds: Learning to be Creative: Learning to be Creative. Chicester: Capstone

Taverniers, M. (2003). "Grammatical Metaphor in SFL: A historiography of the 
introduction and initial study of the concept". In Vandenbergen, A.M, M. Taverniers and L. Ravelli (Eds) Grammatical Metaphors: Views from Systemic Functional Linguistics. Amsterdam: John Benjamins.

Thompson, G. (2014). Introducing Functional Grammar. London: Routledge. Douglas Arnold et al. 1994. Machine Translation - An Introductory Guide. Oxford University Press.

M. A. K. Halliday. 1996. "Things and Relations". In: Reading Science: cricital and functional perspectives on discourses of science. London: Routledge. Heather Holmback, Serena Shubert and Jan Spyridakis.

Saragih, A. (2012). Variations and Functional Varieties of Language. Medan.(Unpublished)

Searle, J. R. (1993). Metaphor. In Andrew Ortony (ed) Metaphor and Thought. New York: Cambridge University Press. 83-111. 